\title{
EVALUASI PELAKSANAAN SERTIFIKASI PRODUKSI PANGAN INDUSTRI RUMAH TANGGA (SPP-IRT) DI BANYUWANGI
}

Fatma Nur Ardiati ${ }^{1}$, Septa Indra Puspikawati ${ }^{2}$

${ }^{1}$ Program Studi S1 Kesehatan Masyarakat PSDKU Universitas Airlangga di Banyuwangi ${ }^{2}$ Departemen Gizi Kesehatan, Program Studi S1 Kesehatan Masyarakat PSDKU UNAIR di Banyuwangi

fatma.nur.ardiati-2015@fkm.unair.ac.id

\begin{abstract}
The right to obtain safe and nutritious food is the same level as the right to be free from hunger. In order to maintain food sefety, every food and beverage circulated must obtain a distribution permit in accordance with the provisions of the laws and regulation. This research aims to determine evaluation of SPP-IRT implementation in the food home industry in Banyuwangi with Indonesia National Agency of Drug and Food Control Number Hk.03.1.23.04.12.2205 of 2012 on guidelines for the provision of food production certificate of home industry. The type of this research is observational research based on Indonesia National Agency of Drug and Food Control Number Hk.03.1.23.04.12.2205 of 2012 on guidelines for the provision of food production certificate of home industry.There are four stages for SPP-IRT. In the third stage, the inspection of home industry food production facilities was observed in $15^{\text {th }}$ food home industry in Banyuwangi along with District Food Inspector (DFI). This research was also carried out by indept interview with two DFI. The results showed that the implementation for SPP-IRT was good. First, acceptance of the application is appropriate. Second, Food safety elucidation is appropriate. Third, the inspection of production facilities is appropriate. Fourth, giving product number of home industry is appropriate. Overall, implementation of SPP-IRT in Banyuwangi already in accordance with Indonesia National Agency of Drug and Food Control Number Hk.03.1.23.04.12.2205 of 2012 on guidelines on the provision of food production certificate of home industry.
\end{abstract}

Keywords : SPP-IRT, IRTP, Number of P-IRT, food safety

\begin{abstract}
ABSTRAK
Hak untuk memperoleh pangan yang aman dan bergizi sama tingkatannya dengan hak untuk bebas dari kelaparan. Demi menjaga keamanan pangan, setiap makanan dan minuman yang diedarkan harus mendapat izin edar sesuai dengan ketentuan peraturan perundang-undangan. Penelitian ini bertujuan mengetahui evaluasi pelaksanaan SPP-IRT pada industri rumah tangga pangan di Banyuwangi dengan Perka BPOM RI Nomor Hk.03.1.23.04.12.2205 Tahun 2012 Tentang Pedoman Pemberian Sertifikat Produksi Pangan Industri Rumah Tangga. Jenis penelitian ini adalah penelitian observasional yang berpedoman pada Perka BPOM RI Nomor Hk.03.1.23.04.12.2205 Tahun 2012 Tentang Pedoman Pemberian Sertifikat Produksi Pangan Industri Rumah Tangga. Ada 4 tahap dalam pemberian sertifikat produksi PIRT. Pada tahap ketiga yaitu pemeriksaan sarana produksi PIRT, dilakukan observasi pada 15 Industri Rumah Tangga Pangan (IRTP) di Banyuwangi bersama dengan petugas pangan Dinas Kesehatan Banyuwangi. Penelitian ini juga dilakukan dengan indept interview kepada 2 orang petugas pengawas pangan. Hasil penelitian menunjukkan bahwa pelaksanaan SPP-IRT di Banyuwangi sudah baik. Pertama, penerimaan pengajuan permohonan SPP-IRT di Banyuwangi sudah sesuai. Kedua, penyuluhan keamanan pangan sudah sesuai. Ketiga, pemeriksaan sarana produksi PIRT sudah sesuai; dan keempat, pemberian Nomor P-IRT sudah sesuai. Secara keseluruhan, pelaksanaan sertifikasi produksi pangan bagi industri rumah tangga di Banyuwangi sudah sesuai dengan Perka BPOM RI Nomor Hk.03.1.23.04.12.2205 Tahun 2012 Tentang Pedoman Pemberian Sertifikat Produksi Pangan Industri Rumah Tangga.
\end{abstract}

Kata Kunci: SPP-IRT, IRTP, Nomor P-IRT, keamanan pangan 


\section{PENDAHULUAN}

Menurut Undang-Undang No.36 tahun 2009 tentang Kesehatan pasal 111 ayat (1) bahwa makanan dan minuman yang dipergunakan pada standar dan/atau persyaratan kesehatan (UU RI, 2009). Hal ini dikarenakan makanan merupakan hal yang penting bagi kesehatan manusia. Pemenuhan pangan yang aman dan bermutu merupakan hak asasi setiap manusia.

Disisi lain, makanan dan minuman merupakan reservoar penyakit yang dapat menyebabkan gangguan kesehatan masyarakat yang biasa dikenal dengan Food Borne Disease. Food Borne Disease atau Penyakit Bawaan Makanan ini biasanya bersifat toksik maupun infeksius, disebabkan oleh agen penyakit yang masuk kedalam tubuh melalui konsumsi makanan yang terkontaminasi (WHO, 2005). Makanan yang terkontaminasi oleh mikroba patogen atau bahan kimia berbahaya seperti toksin alami, pestisida, logam berat, dan lain-lain jika dikonsumsi oleh manusia dapat menyebabkan keracunan pangan.

Selama tahun 2015 BPOM telah mencatat 61 Kejadian Luar Biasa (KLB) keracunan pangan yang berasal dari 34 Propinsi. Dilaporkan jumlah orang yang terpapar sebanyak 8.263 orang, sedangkan kasus KLB keracunan pangan (case) yang dilaporkan sebanyak 2.251 orang sakit dan 3 orang meninggal dunia. Berdasarkan data tersebut diketahui nilai Attack Rate (AR) sebesar 42,5\% dan Case Fatality Rate (CFR) sebesar 0,63\%. Adapun nilai Incident Rate (IR) sebesar 0.95 (Sparringa, 2016).

Sedangkan di Indonesia sendiri bencana non alam yang paling sering terjadi yaitu bencana KLB- Keracunan (41\%), diikuti oleh kecelakaan transportasi (26\%), dan kebakaran $(20 \%)$. Jumlah korban meninggal terbanyak diakibatkan oleh kecelakaan transportasi, yakni sebanyak 252 orang, diikuti oleh kebakaran sebanyak 42 orang, dan KLB keracunan sebanyak 34 orang. Sedangkan bencana non alam yang paling banyak menimbulkan korban luka berat/rawat inap yaitu KLB keracunan dengan 1.945 orang, kemudian kecelakaan transportasi sebanyak 193 orang, dan gagal teknologi dengan 67 orang. Bencana dengan korban luka ringan/rawat jalan terbanyak yakni bencana KLB keracunan dengan 2.566 orang, kemudian kecelakaan transportasi dengan 391 orang dan kebakaran dengan 112 orang (Kementrian Kesehatan RI, 2017).

Kejadian KLB penyakit dan keracunan di Jawa Timur masih tinggi dari tahun ke tahun.
Beberapa kasus penyakit mengalami penurunan dan sebagian mengalami kenaikan. KLB keracunan makanan terbanyak pada tahun 2015 dengan jumlah kasus sebesar 957 kasus dan menurun menjadi 43 kasus pada 2016 yang terjadi di hampir semua wilayah kabupaten/kota di Jawa Timur (Dinkes Jatim, 2016).

Menurut data Profil Kesehatan Banyuwangi, pada tahun 2014 ditemukan 15 KLB. Penanganan dan penanggulangan KLB di kabupaten Banyuwangi sudah dilaksanakan dalam kurun waktu kurang dari 24 jam setiap kasusnya pencapaian $100 \%$ dari kasus yang dilaporkan. Jenis KLB yang terjadi di Kabupaten Banyuwangi, Diphteri ditemukan sebanyak 12 kasus. Kemudian keracunan makanan ditemukan sebanyak 2 kasus. Pada tahun 2015 keracunan makanan mengalami kenaikan sebanyak 176 kasus. Sedangkan pada tahun 2016, tidak ditemukan kasus keracunan makanan. Meskipun demikian, KLB keracunan makanan merupakan suatu kejadian yang harus diwaspadai (Dinas Kesehatan Kabupaten Banyuwangi, 2017).

Oleh karena itu pada ayat (2) UndangUndang No.36 tahun 2009 tentang Kesehatan dijelaskan bahwa makanan dan minuman hanya dapat diedarkan setelah mendapat izin edar sesuai dengan ketentuan peraturan perundang-undangan. Peraturan Kepala Badan Pengawas Obat dan Makanan Republik Indonesia Nomor Hk.03.1.23.04.12.2205 Tahun 2012 tentang Pedoman Pemberian Sertifikat Produksi Pangan Industri Rumah Tangga menjelaskan tata cara pengelola industri rumah tangga mendapatkan nomor P-IRT sebagai bentuk legalitas produk (Kepala BPOM, 2012a).

Pemerintah berwenang dan bertanggung jawab mengatur dan mengawasi produksi, pengolahan, pendistribusian makanan, dan minuman seperti yang tersurat pada UndangUndang No.36 tahun 2009 tentang Kesehatan pasal 112, dalam hal ini termasuk Industri Rumah Tangga Pangan (IRTP). Pemberian sertifikat produksi pangan industri rumah tangga wajib diselenggarakan oleh Pemerintah Daerah Kabupaten/Kota. Sama halnya dengan pelaksanaan Sertifikasi Produksi Pangan Industri Rumah Tangga (SPP-IRT) di Kabupaten Banyuwangi diselenggarakan oleh Dinas kesehatan Kabupaten Banyuwangi. Oleh karena itu, penelitian ini bermaksud untuk mengetahui evaluasi pelaksanaan sertifikasi produksi pangan pada industri rumah tangga.

Menurut data Dinas Kesehatan Kabupaten Banyuwangi, mulai dari tahun 2011 hingga tahun 2017 ini jumlah IRTP di Banyuwangi \pm 577 buah, 
baik yang masih aktif maupun yang sudah mati. Pada tahun 2012 dari 77 IRTP yang mengajukan SPP-IRT hanya 5 IRTP yang melakukan perpanjangan pada tahun 2017 karena mengingat masa berlaku SPP-IRT hanya 5 tahun. Dari data tersebut hanya $5.6 \%$ IRTP yang melakukan perpanjangan SPP-IRT. Hal ini dikarenakan kurangnya kesadaran pengelola industri rumah tangga dalam menjamin mutu produk pangan

\section{METODE}

Penelitian ini merupakan jenis penelitian observasional. Penelitian dilakukan pada Bulan Maret-April 2018 di Banyuwangi. Penelitian ini mengevaluasi pelaksanaan Sertifikasi Produksi Pangan Industri Rumah Tangga (SPP-IRT) di Kabupaten Banyuwangi dengan Peraturan Kepala Badan Pengawas Obat Dan Makanan Republik Indonesia Nomor Hk.03.1.23.04.12.2205 Tahun 2012 Tentang Pedoman Pemberian Sertifikat Produksi Pangan Industri Rumah Tangga.

Data dalam penelitian ini menggunakan data primer dan data sekunder. Data primer didapat dari hasil observasi dan indept interview kepada petugas pengawas pangan Dinas Kesehatan Banyuwangi sebagai penyelenggara program, guna menggali informasi lebih luas. Sementara data sekunder diperoleh dari Peraturan Kepala Badan Pengawas Obat Dan Makanan Republik Indonesia Nomor Hk.03.1.23.04.12.2205 Tahun 2012 Tentang Pedoman Pemberian Sertifikat Produksi Pangan Industri Rumah Tangga, serta data dari Dinas Kesehatan Kabupaten Banyuwangi.

Ada 4 tahap yang harus dilaksanakan dalam pemberian sertifikat produksi pangan bagi industri rumah tangga. Pertama, penerimaan pengajuan permohonan SPP-IRT. Pada tahap ini peneliti membandingkan pelaksanaannya dengan Peraturan Kepala Badan Pengawas Obat Dan Makanan Republik Indonesia Nomor Hk.03.1.23.04.12.2205 Tahun 2012 Tentang Pedoman Pemberian Sertifikat Produksi Pangan Industri Rumah Tangga. Pada tahap pertama ini dikatakan sesuai jika telah memenuhi formulir permohonan SPP-IRT yang harus dilengkapi sebagai berikut: nama jenis pangan; nama dagang; jenis kemasan; berat bersih/isi bersih (mg/g/kg atau $\mathrm{ml} / \mathrm{l} / \mathrm{kl})$; komposisi; tahapan produksi; nama, alamat, kode pos dan nomor telepon IRTP; nama pemilik; nama penanggungjawab; informasi tentang masa kadaluwarsa; informasi tentang kode produksi. Dokumen lain antara lain: surat keterangan atau izin usaha dari Instansi yang berwenang dan rancangan label pangan.

Kedua, tahap penyuluhan keamanan pangan. Pada tahap kedua ini peniliti membandingkan pelaksanaannya dengan Peraturan Kepala Badan Pengawas Obat Dan Makanan Republik Indonesia Nomor Hk.03.1.23.04.12.2205 Tahun 2012 Tentang Pedoman Pemberian Sertifikat Produksi Pangan Industri Rumah Tangga. Penyuluhan keamanan pangan dikatakan sesuai jika memenuhi beberapa ketentuan sebagai berikut: 1) Penyelenggara Penyuluhan Keamanan Pangan dikoordinasikan oleh Bupati / Walikota c.q. Dinas Kesehatan Kabupaten / Kota; 2) Kriteria Tenaga Penyuluh Keamanan Pangan (PKP) adalah Pegawai Negeri Sipil (PNS) yang memiliki Sertifikat kompetensi di bidang penyuluhan keamanan pangan dari Badan POM dan ditugaskan oleh Bupati / Walikota c.q. Dinas Kesehatan Kabupaten / Kota; 3) Narasumber pada penyuluhan keamanan pangan adalah tenaga PKP yang kompeten dari Dinas Kesehatan Kabupaten / Kota dan Balai Besar/Balai POM setempat; 4) Peserta Penyuluhan Keamanan Pangan adalah pemilik atau penanggung jawab IRTP; 5) Materi Penyuluhan Keamanan Pangan terdiri dari: materi utama yang meliputi Peraturan PerundangUndangan di Bidang Pangan ; Keamanan dan Mutu pangan; Teknologi Proses Pengolahan Pangan; Prosedur Operasi Sanitasi yang Standar (Standard Santitation Operating Procedure /SSOP); Cara Produksi Pangan Yang Baik untuk Industri Rumah Tangga (CPPB-IRT); Penggunaan Bahan Tambahan Pangan (BTP); Persyaratan Label dan Iklan Pangan. Adapun materi pendukung yaitu pencantuman label halal serta etika bisnis dan pengembangan jejaring bisnis IRTP; 6) Metode Penyuluhan Keamanan Pangan: diberikan dalam bentuk ceramah, diskusi, demonstrasi atau peragaan simulasi, serta melalui pemutaran video dan cara lain yang mampu mendukung pemahaman keamanan pangan; 7) Sertifikat ini diberikan kepada pemilik atau penanggungjawab yang telah lulus mengikuti penyuluhan keamanan pangan dengan hasil evaluasi minimal nilai cukup yaitu 60 .

Ketiga, pemeriksaan sarana produksi pangan industri rumah tangga. Observasi ini dilakukan selama satu bulan pada 15 Industri Rumah Tangga Pangan (IRTP) dari 50 IRTP di Banyuwangi yang mengikuti Penyuluhan Keamanan Pangan. Pengambilan sampel tersebut berdasarkan atas penerimaan pengajuan permohonan SPP-IRT yaitu diambil dari jumlah industri rumah tangga pangan mengajukan permohonan SPP-IRT yang disertai kelengkapan persyaratan kepada Dinas Kesehatan Banyuwangi. 
Pada tahap ini dilakukan oleh tenaga pengawas pangan dari Dinas Kesehatan bersama peneliti dengan membandingkan pelaksanaanya pada Peraturan Kepala Badan Pengawas Obat Dan Makanan Republik Indonesia Nomor Hk.03.1.23.04.12.2207 Tahun 2012 Tentang Tata Cara Pemeriksaan Sarana Produksi Pangan Industri Rumah Tangga. Pemeriksaan dianggap sesuai jika dilaksanakan berdasarkan Formulir Pemeriksaan Sarana Produksi Pangan Industri Rumah Tangga yang terdapat pada Perka BPOM RI Nomor Hk.03.1.23.04.12.2207 Tahun 2012 Tentang Tata Cara Pemeriksaan Sarana Produksi Pangan Industri Rumah Tangga (Kepala BPOM, 2012). Dalam peninjauan lokasi IRTP, ada beberapa elemen yang harus diperiksa antara lain : Lokasi dan Lingkungan Produksi; Bangunan dan Fasilitas ; Peralatan Produksi; Suplai Air atau Sarana Penyediaan Air; Fasilitas dan Kegiatan Higiene dan Sanitasi; Kesehatan dan Higiene Karyawan ; Pemeliharaan dan Program Higiene dan Sanitasi; Penyimpanan; Pengendalian Proses; Pelabelan Pangan; Pengawasan Oleh Penganggung Jawab; Penarikan Produk; Pencatatan dan Dokumentasi, dan Pelatihan Karyawan.

Pencantuman label pangan yang benar harus sesuai dengan PP No. 69 Tahun 1999 : Label dan Iklan Pangan, terdapat 7 poin yang harus tercantum dalam pembuatan label antara lain : nama produk; komposisi (dari banyaksedikit); berat bersih (gram/g) atau isi bersih (ml); nama dan alamat pihak yang memproduksi (Diproduksi oleh :........... Kec, Kab, Indonesia, Kode Pos) ; baik digunakan sebelum : tanggal, bulan, tahun ; kode produksi ; PIRT No.....

Keempat, pemberian Nomor P-IRT. Pada tahap ini peneliti membandingkan pelaksanaannya dengan Peraturan Kepala Badan Pengawas Obat Dan Makanan Republik Indonesia Nomor Hk.03.1.23.04.12.2205 Tahun 2012 Tentang Pedoman Pemberian Sertifikat Produksi Pangan Industri Rumah Tangga. Pemberian Nomor PIRT harus berdasarkan sebagai berikut: Nomor P- IRT minimal terdiri dari 15 (lima belas) digit; Penjelasan 15 (lima belas) digit sebagai berikut : digit ke-1 menunjukkan kode jenis kemasan; digit ke-2 dan 3 menunjukkan nomor urut/kode jenis pangan IRTP; digit ke- 4,5,6 dan 7 menunjukkan kode propinsi dan kabupaten/kota; digit ke 8 dan 9 menunjukkan nomor urut pangan IRTP yang telah memperoleh SPP-IRT; digit ke- 10,11,12 dan 13 menunjukkan nomor urut IRTP di kabupaten/kota yang bersangkutan; digit ke 14 dan 15 menunjukkan tahun berakhir masa berlaku; Nomor P-IRT diberikan untuk 1 (satu) jenis pangan IRT; Setiap perubahan, baik penambahan maupun pengurangan provinsi, kabupaten/kota, pemberian nomor disesuaikan dengan kode baru untuk Provinsi, Kabupaten, dan Kota yang diterbitkan oleh instansi yang berwenang dalam penerbitan kode propinsi, kabupaten dan kota.Selain memenuhi keempat tahap diatas, berdasarkan Peraturan Kepala Badan Pengawas Obat Dan Makanan Republik Indonesia Nomor Hk.03.1.23.04.12.2205 Tahun 2012 Tentang Pedoman Pemberian Sertifikat Produksi Pangan Industri Rumah Tangga bahwa pemeberian SPP-IRT harus dibuktikan dengan sertifikat penyuluhan keamanan pangan dan hasil rekomendasi pemeriksaan sarana produksi pangan industri rumahtangga. 


\section{HASIL}

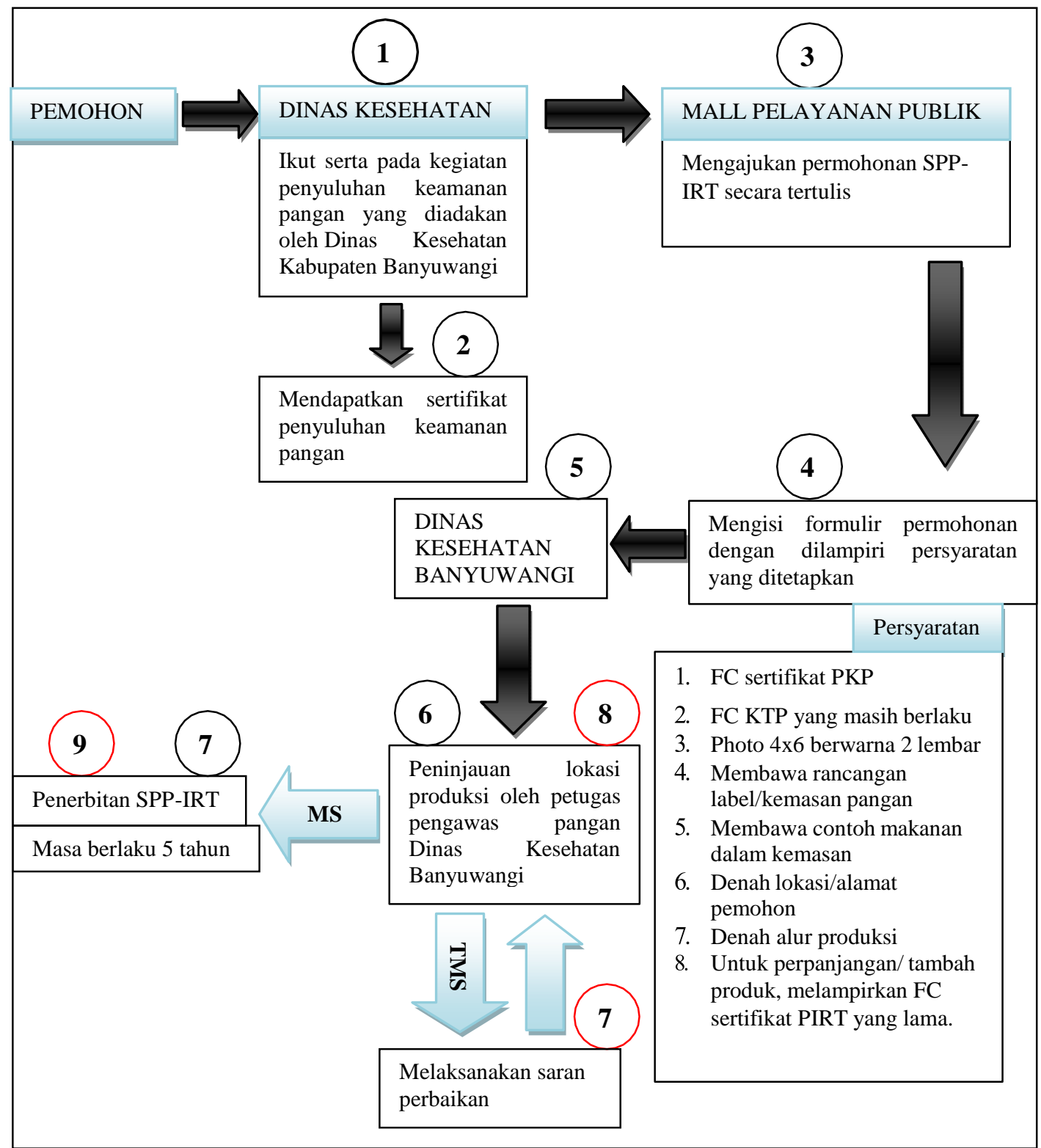

Sumber: Dinas Kesehatan Kab. Banyuwangi

Gambar 1. Mekanisme mendapatkan SPP-IRT di Banyuwangi 


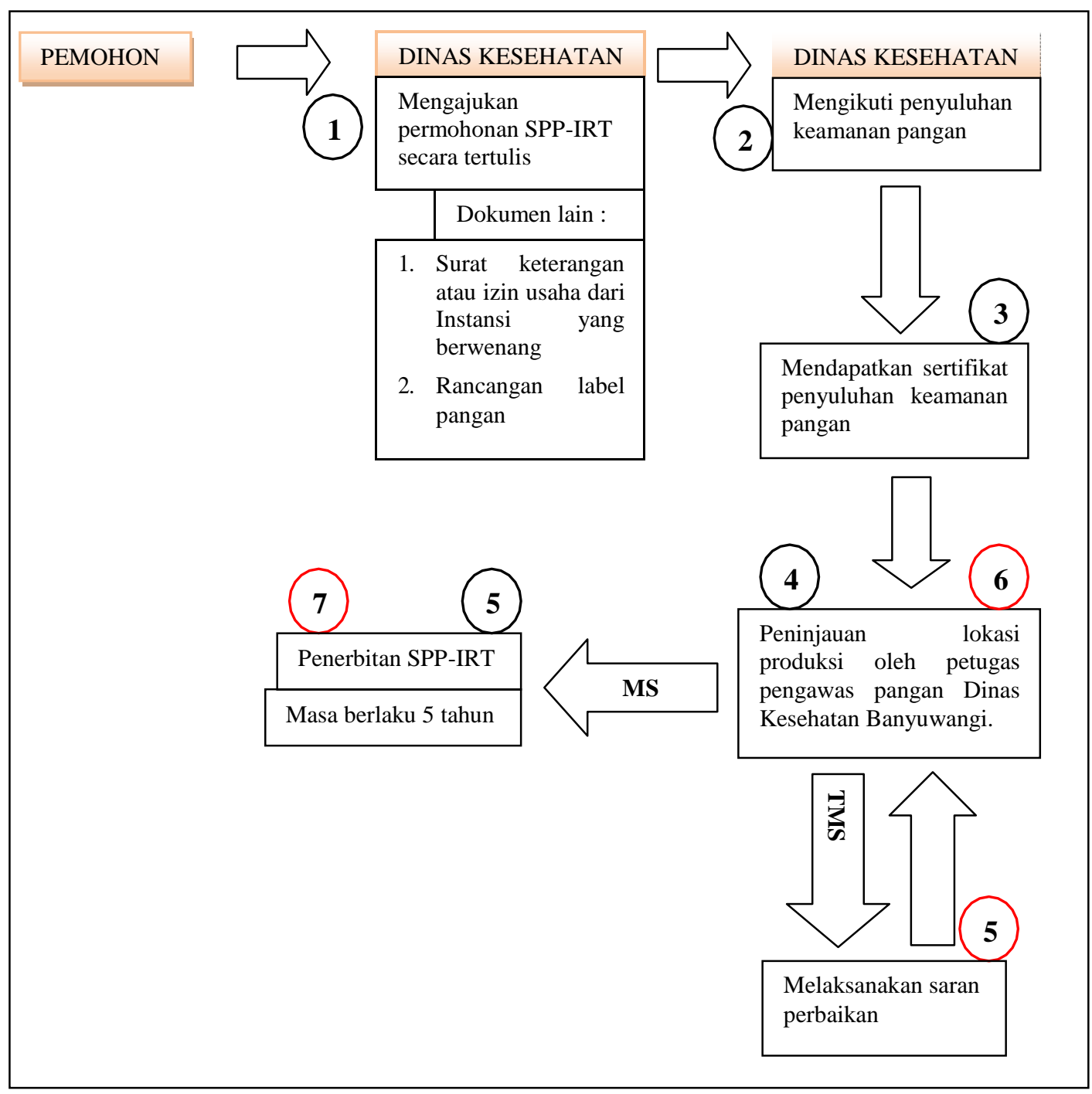

Sumber : Perka BPOM, 2009

Gambar 2. Mekanisme mendapatkan SPP-IRT (Perka BPOM)

Hasil penelitian menunjukkan bahwa terdapat pebedaan letak tahap pada mekanisme mendapatkan SPP-IRT di Banyuwangi dengan Peraturan Kepala Badan Pengawas Obat dan Makanan Republik Indonesia Nomor Hk.03.1.23.04.12.2205 Tahun 2012 Tentang Pedoman Pemberian Sertifikat Produksi Pangan Industri Rumah Tangga. Perbedaannya hanya terletak pada tahap pertama. Pelaksanaan SPPIRT yang terjadi di Banyuwangi, penyuluhan keamanan pangan terletak pada tahap pertama. Peserta penyuluhan keamanan merupakan semua penanggungjawab IRTP dengan pemberian kuota 60 peserta setiap pelaksanaannya. Penyuluhan keamanan pangan dilaksanakan setiap 3 kali dalam setahun. Sertifikat hasil penyuluhan keamanan pangan akan digunakan sebagai syarat pada tahap pengajuan permohonan SPP-IRT.
Pada Perka BPOM, penyuluhan keamanan pangan terletak pada tahap kedua setelah mengajukan permohonan. Pengajuan permohonan SPP-IRT ini tanpa disertai sertifikat penyuluhan keamanan pangan. Sehingga peninjauan lokasi tidak bisa dilakukan sampai mendapatkan sertifikat penyuluhan keamanan pangan. Peserta penyuluhan keamanan pangan merupakan semua IRTP yang mengajukan permohonan SPP-IRT. Secara keseluruhan ketentuan setiap tahap pelaksanaan pemberian SPP-IRT di Banyuwangi sudah sesuai dengan Peraturan Kepala Badan Pengawas Obat dan Makanan Republik Indonesia Nomor Hk.03.1.23.04.12.2205 Tahun 2012 tentang Pedoman Pemberian Sertifikat Produksi Pangan Industri Rumah Tangga. Menurut Peraturan Kepala Badan Pengawas Obat dan Makanan Republik Indonesia Nomor 
Hk.03.1.23.04.12.2205 Tahun 2012 Tentang Pedoman Pemberian Sertifikat Produksi Pangan Industri Rumah Tangga pasal 2 ayat (2-3) bahwa
SPP-IRT diberikan setelah IRTP memenuhi persyaratan.
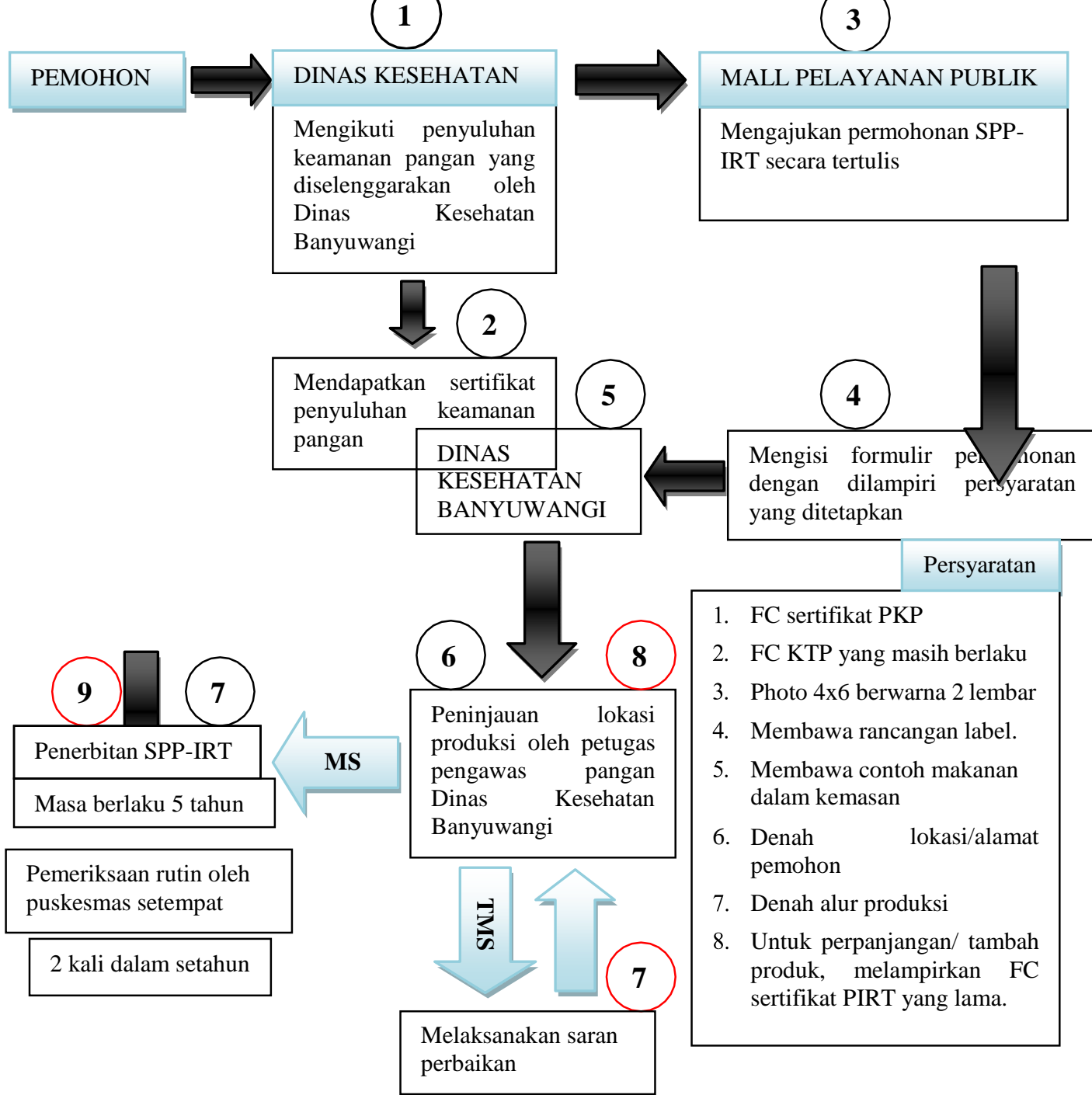

Sumber: Dinas Kesehatan Kab. Banyuwangi

Gambar 3. Alur Pemeriksaan Rutin IRTP di Banyuwangi

Hasil penelitian menununjukkan bahwa alur pemeriksaan sarana produksi pangan IRTP seacara rutin di Banyuwangi sudah sesuai dengan Peraturan Kepala Badan Pengawas Obat dan Makanan Republik Indonesia Nomor Hk.03.1.23.04.12.2205 Tahun 2012 Tentang Pedoman Pemberian Sertifikat Produksi Pangan Industri Rumah Tangga. Setelah melakukan pengecekan awal akan dilakukan pemeriksaan rutin sarana produksi pangan oleh tenaga pengawas pangan dari puskesmas setempat yang diberi kewenangan oleh Dinas Kesehatan Banyuwangi. Pemeriksaan dilakukan 3 kali dalam setahun yaitu 1 kali pemeriksaan awal dan 2 kali pemeriksaan rutin. 
Tabel 1. Permohonan Pengajuan SPP-IRT di Banyuwangi

\begin{tabular}{|c|c|c|}
\hline \multicolumn{3}{|c|}{ Syarat Perrmohonan Pengajuan SPP-IRT } \\
\hline \multirow{2}{*}{$\begin{array}{c}\text { Perka } \\
\text { BPOM RI }\end{array}$} & \multicolumn{2}{|c|}{ Dinas Kesehatan Banyuwangi } \\
\hline & Sesuai & $\begin{array}{l}\text { Tidak } \\
\text { Sesuai }\end{array}$ \\
\hline Nama jenis pangan & $\sqrt{ }$ & \\
\hline Nama dagang & $\sqrt{ }$ & \\
\hline Jenis kemasan & $\sqrt{ }$ & \\
\hline Berat bersih/isi bersih $(\mathrm{mg} / \mathrm{g} / \mathrm{kg}$ atau $\mathrm{ml} / \mathrm{l} / \mathrm{kl})$ & $\sqrt{ }$ & \\
\hline Komposisi & $\sqrt{ }$ & \\
\hline Tahapan produksi & $\sqrt{ }$ & \\
\hline Nama, alamat, kode pos dan nomor telepon IRTP & $\sqrt{ }$ & \\
\hline Nama pemilik & $\sqrt{ }$ & \\
\hline Nama penanggungjawab & $\sqrt{ }$ & \\
\hline Informasi tentang masa kadaluwarsa & $\sqrt{ }$ & \\
\hline Informasi tentang kode produksi & $\sqrt{ }$ & \\
\hline $\begin{array}{l}\text { Surat keterangan atau izin usaha dari Instansi yang } \\
\text { berwenang }\end{array}$ & $\sqrt{ }$ & \\
\hline Rancangan label pangan & $\sqrt{ }$ & \\
\hline
\end{tabular}

Sumber: Dinas Kesehatan Kab. Banyuwangi

Hasil penelitian menunjukkan bahwa kelengkapan permohonan untuk mengajukan SPP-IRT di Banyuwangi sudah sesuai dengan Peraturan Kepala Badan Pengawas Obat dan Makanan Republik Indonesia Nomor Hk.03.1.23.04.12.2205 Tahun 2012 Tentang
Pedoman Pemberian Sertifikat Produksi Pangan Industri Rumah Tangga. Semua persyaratan yang tersurat dalam Perka BPOM sudah tercantum dalam Formulir Permohonan Pengajuan SPP-IRT di Banyuwangi.

Tabel 2. Pelaksanaan Penyuluhan Keamanan Pangan di Banyuwangi

\begin{tabular}{|c|c|c|}
\hline \multicolumn{3}{|l|}{$\begin{array}{l}\text { Penyuluhan Keamanan } \\
\text { Pangan }\end{array}$} \\
\hline \multirow{2}{*}{$\begin{array}{l}\text { Perka } \\
\text { BPOM RI }\end{array}$} & \multicolumn{2}{|c|}{$\begin{array}{c}\text { Dinas Kesehatan } \\
\text { Banyuwangi }\end{array}$} \\
\hline & Sesuai & $\begin{array}{l}\text { Tidak } \\
\text { Sesuai }\end{array}$ \\
\hline Penyelenggara keamanan pangan dari Dinas Kesehatan Kab/Kota & $\mathrm{v}$ & \\
\hline $\begin{array}{l}\text { Kriteria Tenaga Penyuluh Keamanan Pangan (PKP) adalah Pegawai } \\
\text { Negeri Sipil } \\
\text { (PNS) yang memiliki Sertifikat kompetensi di bidang penyuluhan } \\
\text { keamanan pangan dari Badan POM }\end{array}$ & $\sqrt{ }$ & \\
\hline $\begin{array}{l}\text { Tenaga PKP yang kompeten dari Dinas Kesehatan Kabupaten / Kota } \\
\text { dan Balai Besar/Balai POM setempat. }\end{array}$ & $\sqrt{ }$ & \\
\hline $\begin{array}{l}\text { Peserta Penyuluhan Keamanan Pangan adalah pemilik / penanggung } \\
\text { jawab IRTP }\end{array}$ & $\sqrt{ }$ & \\
\hline \multicolumn{3}{|l|}{ Materi Penyuluhan Keamanan Pangan } \\
\hline a. Peraturan perundang-undangan di bidang pangan & $\mathrm{V}$ & \\
\hline b. Keamanan dan Mutu pangan & $\mathrm{V}$ & \\
\hline c. Teknologi Proses Pengolahan Pangan & & $\sqrt{ }$ \\
\hline $\begin{array}{l}\text { d. Prosedur Operasi Sanitasi yang Standar (Standard } \\
\text { Santitation Operating Procedure /SSOP) }\end{array}$ & & $\sqrt{ }$ \\
\hline $\begin{array}{l}\text { e. Cara Produksi Pangan Yang Baik untuk Industri } \\
\text { Rumah Tangga (CPPB-IRT). }\end{array}$ & $\sqrt{ }$ & \\
\hline f. Penggunaan Bahan Tambahan Pangan (BTP) & $\sqrt{ }$ & \\
\hline
\end{tabular}


Lanjutan

Tabel 2. Pelaksanaan Penyuluhan Keamanan Pangan di Banyuwangi

\begin{tabular}{|c|c|c|}
\hline \multicolumn{3}{|l|}{$\begin{array}{c}\text { Penyuluhan Keamanan } \\
\text { Pangan }\end{array}$} \\
\hline \multirow{2}{*}{$\begin{array}{c}\text { Perka } \\
\text { BPOM RI }\end{array}$} & \multicolumn{2}{|c|}{$\begin{array}{c}\text { Dinas Kesehatan } \\
\text { Banyuwangi }\end{array}$} \\
\hline & Sesuai & $\begin{array}{l}\text { Tidak } \\
\text { Sesuai }\end{array}$ \\
\hline g. Persyaratan Label dan Iklan Pangan & $\sqrt{ }$ & \\
\hline h. Pencantuman label Halal & $\sqrt{ }$ & \\
\hline i. Etika Bisnis dan Pengembangan Jejaring Bisnis IRTP & $\sqrt{ }$ & \\
\hline $\begin{array}{l}\text { Materi penyuluhan keamanan pangan disampaikan dalam bentuk } \\
\text { ceramah, diskusi, demonstrasi/peragaan simulasi, pemutaran video } \\
\text { dan cara-cara lain yang } \\
\text { mendukung pemahaman keamanan pangan. }\end{array}$ & $\sqrt{ }$ & \\
\hline $\begin{array}{l}\text { Peserta Penyuluhan Keamanan Pangan dengan hasil evaluasi } \\
\text { minimal nilai cukup } \\
\text { yaitu } 60 \text { dinyatakan LULUS. }\end{array}$ & $\sqrt{ }$ & \\
\hline
\end{tabular}

Sumber: Dinas Kesehatan Kab. Banyuwangi

Tabel 3. Hasil Evaluasi Penyuluhan Keamanan Pangan di Banyuwangi

\begin{tabular}{|r|c|c|c|c|c|}
\hline $\begin{array}{c}\text { Nama } \\
\text { IRTP }\end{array}$ & $\begin{array}{c}\text { Hasil } \\
\text { Evaluasi }\end{array}$ & $\begin{array}{c}\text { No. Sertifikat } \\
\text { Penyuluhan } \\
\text { Keamanan } \\
\text { Pangan (PKP) }\end{array}$ & $\begin{array}{c}\text { Nama } \\
\text { IRTP }\end{array}$ & $\begin{array}{c}\text { Hasil } \\
\text { Evaluasi }\end{array}$ & $\begin{array}{c}\text { No. Sertifikat } \\
\text { Penyuluhan } \\
\text { Keamanan Pangan } \\
\text { (PKP) }\end{array}$ \\
\hline A1 & 88 & $1205 / 3510 / 18$ & $\mathrm{~A} 26$ & 76 & $1230 / 3510 / 18$ \\
\hline A2 & 80 & $1206 / 3510 / 18$ & $\mathrm{~A} 27$ & 84 & $1231 / 3510 / 18$ \\
\hline A3 & 80 & $1207 / 3510 / 18$ & $\mathrm{~A} 28$ & 76 & $1232 / 3510 / 18$ \\
\hline A4 & 72 & $1208 / 3510 / 18$ & $\mathrm{~A} 29$ & 80 & $1233 / 3510 / 18$ \\
\hline A5 & 76 & $1209 / 3510 / 18$ & $\mathrm{~A} 30$ & 76 & $1234 / 3510 / 18$ \\
\hline A6 & 76 & $1210 / 3510 / 18$ & $\mathrm{~A} 31$ & 84 & $1235 / 3510 / 18$ \\
\hline A7 & 68 & $1211 / 3510 / 18$ & $\mathrm{~A} 32$ & 72 & $1236 / 3510 / 18$ \\
\hline A8 & 80 & $1212 / 3510 / 18$ & $\mathrm{~A} 33$ & 76 & $1237 / 3510 / 18$ \\
\hline A9 & 96 & $1213 / 3510 / 18$ & $\mathrm{~A} 34$ & 92 & $1238 / 3510 / 18$ \\
\hline A10 & 96 & $1214 / 3510 / 18$ & $\mathrm{~A} 35$ & 76 & $1239 / 3510 / 18$ \\
\hline A11 & 80 & $1215 / 3510 / 18$ & $\mathrm{~A} 36$ & 88 & $1240 / 3510 / 18$ \\
\hline A12 & 88 & $1216 / 3510 / 18$ & $\mathrm{~A} 37$ & 76 & $1241 / 3510 / 18$ \\
\hline A13 & 80 & $1217 / 3510 / 18$ & $\mathrm{~A} 38$ & 72 & $1242 / 3510 / 18$ \\
\hline A14 & 68 & $1218 / 3510 / 18$ & $\mathrm{~A} 39$ & 76 & $1243 / 3510 / 18$ \\
\hline A15 & 80 & $1219 / 3510 / 18$ & $\mathrm{~A} 40$ & 72 & $1244 / 3510 / 18$ \\
\hline A16 & 76 & $1220 / 3510 / 18$ & $\mathrm{~A} 42$ & 68 & $1246 / 3510 / 18$ \\
\hline A17 & 84 & $1221 / 3510 / 18$ & $\mathrm{~A} 43$ & 88 & $1247 / 3510 / 18$ \\
\hline A18 & 68 & $1222 / 3510 / 18$ & $\mathrm{~A} 44$ & 88 & $1248 / 3510 / 18$ \\
\hline A19 & 68 & $1223 / 3510 / 18$ & $\mathrm{~A} 45$ & 84 & $1249 / 3510 / 18$ \\
\hline A20 & 88 & $1224 / 3510 / 18$ & $\mathrm{~A} 46$ & 68 & $1250 / 3510 / 18$ \\
\hline A21 & 92 & $1225 / 3510 / 18$ & $\mathrm{~A} 47$ & 76 & $1251 / 3510 / 18$ \\
\hline A22 & 92 & $1226 / 3510 / 18$ & $\mathrm{~A} 48$ & 60 & $1252 / 3510 / 18$ \\
\hline
\end{tabular}


Lanjutan

Tabel 3. Hasil Evaluasi Penyuluhan Keamanan Pangan di Banyuwangi

\begin{tabular}{|c|c|c|c|c|c|}
\hline $\begin{array}{c}\text { Nama } \\
\text { IRTP }\end{array}$ & $\begin{array}{c}\text { Hasil } \\
\text { Evaluasi }\end{array}$ & $\begin{array}{c}\text { No. Sertifikat } \\
\text { Penyuluhan } \\
\text { Keamanan } \\
\text { Pangan (PKP) }\end{array}$ & $\begin{array}{c}\text { Nama } \\
\text { IRTP }\end{array}$ & $\begin{array}{c}\text { Hasil } \\
\text { Evaluasi }\end{array}$ & $\begin{array}{c}\text { No. Sertifikat } \\
\text { Penyuluhan } \\
\text { Keamanan Pangan } \\
\text { (PKP) }\end{array}$ \\
\hline A23 & 84 & $1227 / 3510 / 18$ & A49 & 72 & $1253 / 3510 / 18$ \\
\hline A24 & 92 & $1228 / 3510 / 18$ & A50 & 84 & $1254 / 3510 / 18$ \\
\hline A25 & 84 & $1229 / 3510 / 18$ & A51 & 84 & $1255 / 3510 / 18$ \\
\hline
\end{tabular}

Sumber: Dinas Kesehatan Kab. Banyuwangi

Hasil penelitian menunjukkan bahwa beberapa ketentuan dalam penyelenggaraan penyuluhan keamanan pangan di Banyuwangi secara keseluruhan sudah sesuai dengan Peraturan Kepala Badan Pengawas Obat dan Makanan Republik Indonesia Nomor Hk.03.1.23.04.12.2205 Tahun 2012 Tentang
Pedoman Pemberian Sertifikat Produksi Pangan Industri Rumah Tangga. Hasil evaluasi kegiatan Penyuluhan Keamanan Pangan dinyatakan LULUS dan mendapatkan sertifikat penyuluhan keamanan pangan dengan nilai tidak kurang dari 60.

Tabel 4. Hasil Pemeriksaan IRTP di Banyuwangi

\begin{tabular}{|c|c|c|c|c|c|c|c|c|c|c|c|c|c|c|}
\hline \multirow{3}{*}{$\begin{array}{l}\text { NAMA } \\
\text { IRTP }\end{array}$} & \multicolumn{14}{|c|}{ ELEMEN PENILAIAN } \\
\hline & \multicolumn{2}{|c|}{$\begin{array}{c}\text { Lokasi dan } \\
\text { Lingkungan } \\
\text { Produksi }\end{array}$} & \multicolumn{2}{|c|}{$\begin{array}{c}\text { Bangunan } \\
\text { dan } \\
\text { Fasilitas }\end{array}$} & \multicolumn{2}{|c|}{$\begin{array}{l}\text { Peralatan } \\
\text { Produksi }\end{array}$} & \multicolumn{2}{|c|}{$\begin{array}{c}\text { Suplai Air } \\
\text { atau } \\
\text { Sarana } \\
\text { Penyediaan } \\
\text { Air }\end{array}$} & \multicolumn{2}{|c|}{$\begin{array}{l}\text { Fasilitas dan } \\
\text { Kegiatan } \\
\text { Higiene dan } \\
\text { Sanitasi }\end{array}$} & \multicolumn{2}{|c|}{$\begin{array}{c}\text { Kesehatan } \\
\text { dan } \\
\text { Higiene } \\
\text { Karyawan }\end{array}$} & \multicolumn{2}{|c|}{$\begin{array}{c}\text { Pemeliharaan } \\
\text { dan Program } \\
\text { Higiene dan } \\
\text { Sanitasi }\end{array}$} \\
\hline & TS & $\mathbf{S}$ & TS & $\mathbf{S}$ & TS & $\mathbf{S}$ & $\mathbf{T S}$ & $\mathbf{S}$ & TS & $\mathbf{S}$ & TS & $\mathbf{S}$ & TS & $\mathbf{S}$ \\
\hline A & & $\sqrt{ }$ & & $\sqrt{ }$ & & $\sqrt{ }$ & & $\sqrt{ }$ & & $\sqrt{ }$ & & $\sqrt{ }$ & & $\sqrt{ }$ \\
\hline $\mathrm{B}$ & & $\sqrt{ }$ & & $\sqrt{ }$ & $\sqrt{ }$ & & & $\sqrt{ }$ & & $\sqrt{ }$ & & $\sqrt{ }$ & & $\sqrt{ }$ \\
\hline $\mathrm{C}$ & & $\sqrt{ }$ & $\sqrt{ }$ & & & $\sqrt{ }$ & & $\sqrt{ }$ & & $\sqrt{ }$ & & $\sqrt{ }$ & & $\sqrt{ }$ \\
\hline $\mathrm{D}$ & & $\sqrt{ }$ & & $\sqrt{ }$ & & $\sqrt{ }$ & & $\sqrt{ }$ & & $\sqrt{ }$ & & $\sqrt{ }$ & & $\sqrt{ }$ \\
\hline $\mathrm{E}$ & & $\sqrt{ }$ & & $\sqrt{ }$ & & $\sqrt{ }$ & & $\sqrt{ }$ & & $\sqrt{ }$ & $\sqrt{ }$ & & & $\sqrt{ }$ \\
\hline $\mathrm{F}$ & & $\sqrt{ }$ & & $\sqrt{ }$ & $\sqrt{ }$ & & & $\sqrt{ }$ & & $\sqrt{ }$ & & $\sqrt{ }$ & $\sqrt{ }$ & \\
\hline G & & $\sqrt{ }$ & & $\sqrt{ }$ & & $\sqrt{ }$ & & $\sqrt{ }$ & & $\sqrt{ }$ & & $\sqrt{ }$ & & $\sqrt{ }$ \\
\hline $\mathrm{H}$ & & $\sqrt{ }$ & & $\sqrt{ }$ & & $\sqrt{ }$ & & $\sqrt{ }$ & & $\sqrt{ }$ & & $\sqrt{ }$ & & $\sqrt{ }$ \\
\hline $\mathrm{I}$ & & $\sqrt{ }$ & & $\sqrt{ }$ & & $\sqrt{ }$ & & $\sqrt{ }$ & & $\sqrt{ }$ & & $\sqrt{ }$ & & $\sqrt{ }$ \\
\hline $\mathrm{J}$ & & $\sqrt{ }$ & & $\sqrt{ }$ & & $\sqrt{ }$ & & $\sqrt{ }$ & & $\sqrt{ }$ & & $\sqrt{ }$ & & $\sqrt{ }$ \\
\hline $\mathrm{K}$ & & $\sqrt{ }$ & $\sqrt{ }$ & & & $V$ & & $\sqrt{ }$ & & $\sqrt{ }$ & & $\sqrt{ }$ & & $V$ \\
\hline $\mathrm{L}$ & & $\sqrt{ }$ & & $\sqrt{ }$ & & $V$ & & $\sqrt{ }$ & & $\sqrt{ }$ & & $\sqrt{ }$ & & $\sqrt{ }$ \\
\hline $\bar{M}$ & & $\sqrt{ }$ & & $V$ & & $V$ & & $\sqrt{ }$ & & $\sqrt{ }$ & & $\sqrt{ }$ & & $V$ \\
\hline $\bar{N}$ & & $\sqrt{ }$ & & $V$ & & $V$ & & $\sqrt{ }$ & & $\sqrt{ }$ & & $\sqrt{ }$ & & $V$ \\
\hline $\mathrm{O}$ & & $\sqrt{ }$ & & $\sqrt{ }$ & & $\sqrt{ }$ & & $\sqrt{ }$ & & $\sqrt{ }$ & & $\sqrt{ }$ & & $\sqrt{ }$ \\
\hline
\end{tabular}


Lanjutan

Tabel 4. Hasil Pemeriksaan IRTP di Banyuwangi

\begin{tabular}{|c|c|c|c|c|c|c|c|c|c|c|c|c|c|c|}
\hline \multirow{3}{*}{$\begin{array}{l}\text { NAMA } \\
\text { IRTP }\end{array}$} & \multicolumn{14}{|c|}{ ELEMEN PENILAIAN } \\
\hline & \multicolumn{2}{|c|}{ Penyimpaan } & \multicolumn{2}{|c|}{$\begin{array}{c}\text { Pengendalian } \\
\text { Proses }\end{array}$} & \multicolumn{2}{|c|}{$\begin{array}{c}\text { Pelabelan } \\
\text { Pangan }\end{array}$} & \multicolumn{2}{|c|}{$\begin{array}{c}\text { Pengawasan } \\
\text { Oleh } \\
\text { Penangggung } \\
\text { Jawab }\end{array}$} & \multicolumn{2}{|c|}{$\begin{array}{l}\text { Penarikan } \\
\text { Produk }\end{array}$} & \multicolumn{2}{|c|}{$\begin{array}{c}\text { Pencatatan } \\
\text { Dan } \\
\text { Dokument } \\
\text { asi }\end{array}$} & \multicolumn{2}{|c|}{$\begin{array}{l}\text { Pelatihan } \\
\text { Karyawan }\end{array}$} \\
\hline & TS & $\mathbf{S}$ & TS & $\mathbf{S}$ & TS & $\mathbf{S}$ & TS & $\mathbf{S}$ & TS & $\mathbf{S}$ & TS & $\mathbf{S}$ & TS & $\mathbf{S}$ \\
\hline A & & $\sqrt{ }$ & & $\sqrt{ }$ & $\sqrt{ }$ & & & $\sqrt{ }$ & & $\sqrt{ }$ & & $\sqrt{ }$ & & $\sqrt{ }$ \\
\hline $\mathrm{B}$ & $\sqrt{ }$ & & & $\sqrt{ }$ & & $\sqrt{ }$ & & $\sqrt{ }$ & & $\sqrt{ }$ & & $\sqrt{ }$ & & $\sqrt{ }$ \\
\hline $\mathrm{C}$ & $\sqrt{ }$ & & & $\sqrt{ }$ & & $\sqrt{ }$ & & $\sqrt{ }$ & & $\sqrt{ }$ & & $\sqrt{ }$ & & $\sqrt{ }$ \\
\hline $\mathrm{D}$ & & $\sqrt{ }$ & & $\sqrt{ }$ & $\sqrt{ }$ & & & $\sqrt{ }$ & & $\sqrt{ }$ & & $\sqrt{ }$ & & $\sqrt{ }$ \\
\hline $\mathrm{E}$ & $\sqrt{ }$ & & & $\sqrt{ }$ & $\sqrt{ }$ & & & $\sqrt{ }$ & & $\sqrt{ }$ & & $\sqrt{ }$ & & $\sqrt{ }$ \\
\hline $\mathrm{F}$ & & $\sqrt{ }$ & & $\sqrt{ }$ & & $\sqrt{ }$ & & $\sqrt{ }$ & & $\sqrt{ }$ & & $\sqrt{ }$ & & $\sqrt{ }$ \\
\hline G & & $\sqrt{ }$ & & $\sqrt{ }$ & & $\sqrt{ }$ & & $\sqrt{ }$ & & $\sqrt{ }$ & & $\sqrt{ }$ & & $\sqrt{ }$ \\
\hline $\mathrm{H}$ & & $\sqrt{ }$ & & $\sqrt{ }$ & $\sqrt{ }$ & & & $\sqrt{ }$ & & $\sqrt{ }$ & & $\sqrt{ }$ & & $\sqrt{ }$ \\
\hline I & & $\sqrt{ }$ & & $\sqrt{ }$ & $\sqrt{ }$ & & & $\sqrt{ }$ & & $\sqrt{ }$ & & $\sqrt{ }$ & & $\sqrt{ }$ \\
\hline $\mathrm{J}$ & & $\sqrt{ }$ & & $\sqrt{ }$ & $\sqrt{ }$ & & & $\sqrt{ }$ & & $\sqrt{ }$ & & $\sqrt{ }$ & & $\sqrt{ }$ \\
\hline $\mathrm{K}$ & & $\sqrt{ }$ & & $\sqrt{ }$ & $\sqrt{ }$ & & & $\sqrt{ }$ & & $\sqrt{ }$ & & $\sqrt{ }$ & & $\sqrt{ }$ \\
\hline $\mathrm{L}$ & & $\sqrt{ }$ & & $\sqrt{ }$ & & $\sqrt{ }$ & & $\sqrt{ }$ & & $\sqrt{ }$ & & $\sqrt{ }$ & & $\sqrt{ }$ \\
\hline $\mathrm{M}$ & & $\sqrt{ }$ & & $\sqrt{ }$ & & $\sqrt{ }$ & & $\sqrt{ }$ & & $\sqrt{ }$ & & $\sqrt{ }$ & & $\sqrt{ }$ \\
\hline $\mathrm{N}$ & & $\sqrt{ }$ & & $\sqrt{ }$ & & $\sqrt{ }$ & & $\sqrt{ }$ & & $\sqrt{ }$ & & $\sqrt{ }$ & & $\sqrt{ }$ \\
\hline $\mathrm{O}$ & & $\sqrt{ }$ & & $\sqrt{ }$ & & $\sqrt{ }$ & & $\sqrt{ }$ & & $\sqrt{ }$ & & $\sqrt{ }$ & & $\sqrt{ }$ \\
\hline
\end{tabular}

Sumber: Dinas Kesehatan Kab. Banyuwangi

Catatan : TS = Tidak memenuhi Syarat $\mathrm{S}=$ memenuhi Syarat

Hasil penelitian menunjukkan bahwa pemeriksaan sarana produksi pangan industri rumah tangga yang dilaksanakan Dinas Kesehatan Banyuwangi sudah sesuai dengan Peraturan Kepala Badan Pengawas Obat Dan Makanan Republik Indonesia Nomor
Hk.03.1.23.04.12.2207 Tahun 2012 Tentang Tata Cara Pemeriksaan Sarana Produksi Pangan Industri Rumah Tangga. Pemberian sertifikat SPP-IRT kepada penanggung jawab IRTP, jika dalam pemeriksaan sarana produksi pangan memenuhi persyaratan yang berlaku. 
Tabel 5. Pemberian Nomor P-IRT di Banyuwangi

\begin{tabular}{|c|c|c|c|c|c|c|c|c|}
\hline \multirow[b]{2}{*}{$\begin{array}{c}\text { NAMA } \\
\text { IRTP }\end{array}$} & \multirow{2}{*}{$\begin{array}{c}\begin{array}{c}\text { Digit } \\
\text { (1) }\end{array} \\
\begin{array}{c}\text { Jenis } \\
\text { kema } \\
\text { s an }\end{array}\end{array}$} & \multirow{2}{*}{$\begin{array}{c}\begin{array}{c}\text { Digit } \\
(2 \text { dan3) }\end{array} \\
\text { nomor } \\
\text { urut/ } \\
\text { kode } \\
\text { jenis } \\
\text { pangan } \\
\text { IRTP }\end{array}$} & \multirow{2}{*}{$\begin{array}{c}\text { Digit } \\
(4,5,6 \text { dan } 7) \\
\begin{array}{c}\text { kode } \\
\text { propinsi dan } \\
\text { kabupaten/ } \\
\text { kota }\end{array}\end{array}$} & \multirow{2}{*}{$\begin{array}{c}\text { Digit } \\
\text { (8 dan 9) } \\
\text { nomor urut } \\
\text { pangan } \\
\text { IRTP yang } \\
\text { telah } \\
\text { memperoleh } \\
\text { SPP-IRT } \\
\end{array}$} & \multirow{2}{*}{$\begin{array}{c}\text { Digiti } \\
(\mathbf{1 0 , 1 1 , 1 2} \\
\text { dan 13) } \\
\text { nomor urut } \\
\text { IRTP di } \\
\text { kabupaten/k } \\
\text { ota yang } \\
\text { bersangkuta } \\
\text { n. } \\
\end{array}$} & \multirow{2}{*}{\begin{tabular}{|c|} 
Digit (14 dan \\
15) \\
tahun \\
berakhi \\
r masa \\
berlaku
\end{tabular}} & \multicolumn{2}{|c|}{ Kesesuaian } \\
\hline & & & & & & & TS & $\mathbf{S}$ \\
\hline A & 2 & 06 & $\begin{array}{c}351 \\
0\end{array}$ & 03 & 0990 & 23 & & $\sqrt{ }$ \\
\hline B & 1 & 11 & $\begin{array}{c}351 \\
0\end{array}$ & 01 & 1161 & 23 & & $\sqrt{ }$ \\
\hline $\mathrm{C}$ & 2 & 06 & $\begin{array}{c}351 \\
0\end{array}$ & 01 & 1163 & 23 & & $\sqrt{ }$ \\
\hline D & 2 & 06 & $\begin{array}{c}351 \\
0\end{array}$ & 01 & 1162 & 23 & & $\sqrt{ }$ \\
\hline $\mathrm{E}$ & 2 & 15 & $\begin{array}{c}351 \\
0\end{array}$ & 01 & 0595 & 23 & & $\sqrt{ }$ \\
\hline $\mathrm{F}$ & 2 & 06 & $\begin{array}{c}351 \\
0\end{array}$ & 01 & 1171 & 23 & & $V$ \\
\hline G & 2 & 06 & $\begin{array}{c}351 \\
0\end{array}$ & 01 & 1170 & 23 & & $V$ \\
\hline $\mathrm{H}$ & 2 & 15 & $\begin{array}{c}351 \\
0\end{array}$ & 01 & 1175 & 23 & & $\sqrt{ }$ \\
\hline I & 2 & 15 & $\begin{array}{c}351 \\
0\end{array}$ & 01 & 1174 & 23 & & 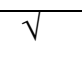 \\
\hline $\mathrm{J}$ & 2 & 06 & $\begin{array}{c}351 \\
0\end{array}$ & 01 & 1176 & 23 & & $\sqrt{ }$ \\
\hline K & 5 & 15 & $\begin{array}{c}351 \\
0\end{array}$ & 01 & 1173 & 23 & & $\sqrt{ }$ \\
\hline $\mathrm{L}$ & 2 & 06 & $\begin{array}{c}351 \\
0\end{array}$ & 01 & 1172 & 23 & & $V$ \\
\hline $\mathrm{M}$ & 2 & 06 & $\begin{array}{c}351 \\
0\end{array}$ & 01 & 1180 & 23 & & $V$ \\
\hline $\mathrm{N}$ & 2 & 13 & $\begin{array}{c}351 \\
0\end{array}$ & 01 & 1177 & 23 & & $\sqrt{ }$ \\
\hline $\mathrm{O}$ & 2 & 15 & $\begin{array}{c}351 \\
0\end{array}$ & 01 & 1179 & 23 & & $\sqrt{ }$ \\
\hline
\end{tabular}

Sumber: Dinas Kesehatan Kab. Banyuwangi

\section{PEMBAHASAN}

Secara keseluruhan, pelaksanaan Sertifikasi Produksi Pangan Industri Rumah Tangga (SPP-IRT) sudah baik, sesuai dengan Peraturan Kepala Badan Pengawas Obat dan Makanan Republik Indonesia Nomor Hk.03.1.23.04.12.2205 Tahun 2012 Tentang Pedoman Pemberian Sertifikat Produksi Pangan Industri Rumah Tangga. Seperti hasil penelitian sebelumnya mengenai evaluasi kebijakan SPPIRT (Ericko, 2016) diperoleh bahwa kebijakan setifikasi produk pangan industri rumah tangga sudah berjalan cukup baik. Akan tetapi masih ada beberapa masalah dan hambatan. Masalah tersebut diantaranya adalah kurangnya sumber daya manusia seperti kurangnya sosialisai mengenai SPP-IRT, serta sumber daya teknologi dalam pemenuhan sarana dan prasarana.

Pelaksanaan sertifikasi produksi pangan industri rumah tangga pada pengelola IRTP di Banyuwangi melalui empat tahap mekanisme sama seperti hasil penelitian sebelumnya (Hermanu, 2014) untuk mendapatkan Nomor PIRT) (Gambar 2) sebagai berikut.

\section{Penyuluhan Keamanan Pangan Bagi Industri Rumah Tangga Pangan}

Dinas Kesehatan Kabupaten Banyuwangi merupakan penyelenggara penyuluhan keamanan pangan yang berhak melaksanakan penyuluhan 
kemanan pangan dan memberikan sertifikat penyuluhan kepada industri rumah tangga pangan. Dinas Kesehatan Kabupaten Banyuwangi sendiri pada tahun 2018 memberikan penyuluhan keamanan pangan kepada Industri Rumah Tangga Pangan (IRTP) sebanyak 3 kali dalam setahun yaitu pada Bulan Maret, Juli, dan November. Pada tahun sebelumnya penyuluhan keamanan pangan dilaksanakan hanya setahun dua kali yaitu pada Bulan April dan Oktober. Perubahan ini dilakukan karena banyaknya permintaan/kebutuhan. Jumlah peserta penyuluhan keamanan pangan setiap kali dilaksanakan maksimal 60 peserta. Pembatasan kuota peserta ini dilakukan karena mengingat lokasi yang tidak mencukupi. Berdasarkan ketentuan penyelenggara penyuluhan keamaan sudah sesuai dengan Perka BPOM yaitu dari Dinas Kesehatan.

Pada tahun 2018 ini, Dinas Kesehatan Kabupaten Banyuwangi melaksanan Penyuluhan Keamanan Pangan (PKP) pada Bulan Maret. Kegiatan PKP dilaksanakan selama dua hari yaitu pada tanggal 22 s/d 23 Maret 2018 di Dinas Kesehatan Kabupaten Banyuwangi. Pemateri penyuluhan keamanan pangan ini dengan mengundang hadirkan dari Badan Pengawas Obat dan Makanan (BPOM) Surabaya dan Dinas Perindustrian dan Perdagangan Banyuwangi, serta dari Dinas Kesehatan Kabupaten Banyuwangi. Dengan demikian sudah sesuai dengan kriteria tenaga penyuluh berdasarkan Perka BPOM.

Berdasarkan Perka BPOM RI Nomor Hk.03.1.23.04.12.2205 Tahun 2012 Tentang Pedoman Pemberian Sertifikat Produksi Pangan Industri Rumah Tangga. Terdapat sembilan materi dalam penyuluhan keamanan pangan. Namun pada pelaksanaanya hanya tujuh materi yang sesuai dari tujuh materi yang diberikan dengan memprioritaskan materi yang paling penting sejalan dengan penelitian sebelumnya (Purba dan Koswara, 2014) diperoleh bahwa Materi penyuluhan keamanan pangan yang disajikan dalam buku Materi Sosialisasi Keamanan Pangan Bagi Industri Rumah Tangga di Kabupaten Cianjur, mencakup berbagai topik, antara lain: 1) Pedoman CPPB IRT, 2) Pelabelan dan Iklan Pangan, 3) Higiene Perorangan/ Karyawan dan Sanitasi Sarana Pengolahan Industri Rumah Tangga Pangan, 4) Berbagai Jenis Bahaya/ Pencemaran serta Cara Mengatasinya, 5) Penyakit- penyakit yang ditimbulkan oleh Pangan serta Pencegahannya, 6) Bahan Tambahan Pangan, dan 7) Peraturan Perundang-undangan di Bidang Pangan. Hal ini dikarenakan keterbatasan waktu pelaksanaannya serta menggantikan topik lainnya dengan topik mengenai tata cara pembuatan SPP- IRT. Metode penyuluhan keamanan dengan menggunakan bentuk ceramah, diskusi, pemutaran video, serta demonstrasi/peragaan simulasi dengan menggunakan sampel makananan yang dibawa oleh pemilik IRTP. Label produk makanan tersebut sebagai contoh desain informasi produk kepada publik. Petugas pengawas pangan beserta pemateri akan melakukan evaluasi isi dari rancangan label sesuai dengan ketentuannya. Materi dan metode penyuluhan keamanan pangan sudah sesuai dengan Perk BPOM.

Peserta Penyuluhan Keamanan Pangan diikuti oleh 50 Pengelola Industri Rumah Tangga Pangan yang ada di Banyuwangi. Pada akhir penyuluha keamanan pangan akan ada evaluasi atau post-test untuk peserta. Post-test ini dilakukan untuk mengetahui seberapa besar hasil pengetahuan dari peserta penyuluhan kemanan pangan. Setiap peserta diberikan satu lembar post test dengan jumlah 25 soal terbagi dalam 10 soal BENAR-SALAH dan 15 soal pilihan ganda. Peserta penyuluhan keamanan pangan dinyatakan LULUS dan mendapatkan sertifikat dalam penyuluhan keamanan pangan, jika nilai post-test dari peserta tidak kurang dari 60 (tabel.2). Jika terdapat peserta yang nilainya kurang dari 60 , maka akan dilakukan post-test ulang. Hal ini sesuai dengan Peraturan Kepala Badan Pengawas Obat Dan Makanan Republik Indonesia Nomor Hk.03.1.23.04.12.2205 Tahun 2012 Tentang Pedoman Pemberian Sertifikat Produksi Pangan Industri Rumah Tangga. Sertifikat Panyuluhan Keamanan Pangan ini akan dijadikan sebagai syarat untuk pembuatan Sertifikat Produksi Pangan Industri Rumah Tangga (SPP-IRT).

Dari hasil post-test peserta penyuluhan keamanan pangan pada tanggal 22-23 Maret 2018 tidak ditemukan nilai yang kurang dari 60 dan semua peserta dinyatakan LULUS dalam penyuluhan keamanan pangan. Penyuluhan keamanan pangan ini diharapkan agar pengelola Industri Rumah Tangga Pangan (IRTP) menghasilkan produk pangan yang memenuhi syarat mutu dan aman untuk dikonsumsi, memenuhi selera atau tuntutan konsumen, serta memberikan jaminan bahwa pangan yang diproduksi aman dan layak dikonsumsi.

Tahap pertama penyuluhan keamanan pangan berjalan sesuai dengan Peraturan Kepala Badan Pengawas Obat Dan Makanan Republik Indonesia Nomor Hk.03.1.23.04.12.2205 Tahun 2012 Tentang Pedoman Pemberian Sertifikat Produksi Pangan Industri Rumah Tangga. 


\section{Penerimaan Pengajuan Permohonan SPP-IRT.}

Bagi pengelola industri rumah tangga pangan yang ingin mendapatkan Sertifikasi Produksi Pangan Rumah Tangga (SPP-IRT), maka harus mengajukan permohonan yang sudah sesuai dengan Perka BPOM RI ke Dinas Kesehatan Banyuwangi (tabel.1). Pengajuan permohonan dilakukan setelah pemilik atau penanggungjawab industri rumah tangga sudah mengikuti penyuluhan keamanan pangan dan mendapatkan sertifikat penyuluhan keamanan pangan. Sertifikat penyuluhan keamanan pangan ini sebagai syarat pengajuan permohonan SPPIRT dan peninjauan lokasi IRTP. Untuk satu dokumen yaitu surat keterangan atau surat ijin usaha dari instansi yang berwenang dikhususkan hanya bagi usaha yang sudah besar dan berjalan.

Adapun berkas lain yang harus dilampirkan dalam pengajuan permohonan SPPIRT antara lain : Pertama, Salinan KTP pemilik atau penanggung jawab yang masih berlaku dan foto $4 \times 6$ berwarna 2 lembar guna keperluan pembuatan sertifkat. Kedua, membawa rancangan label. Ketiga, membawa contoh makanan dalam kemasan untuk mengetahui apakah bahan tersebut termasuk jenis pangan yang diperbolehkan dalam pengajuan SPP-IRT. Keempat, denah lokasi IRTP guna peninjauan lokasi. Kelima, denah alur produksi guna pemeriksaan sarana produksi pangan. Kelima, Salinan sertifikat lama untuk perpanjangan atau tambah produk.

Tahap kedua penerimaan pengajuan permohonan SPP-IRT Dinas Kesehatan Banyuwangi sudah sesuai dengan Peraturan Kepala Badan Pengawas Obat Dan Makanan Republik Indonesia Nomor Hk.03.1.23.04.12.2205 Tahun 2012 Tentang Pedoman Pemberian Sertifikat Produksi Pangan Industri Rumah Tangga.

\section{Pemeriksaan Sarana Produksi Pangan Pada Industri Rumah Tangga}

Kegiatan pemeriksaan berbagai sarana produksi pangan industri rumah tangga dilaksanakan atas pengajuan dari pengelola industri rumah tangga pangan ke Dinas Kesehatan Kabupaten Banyuwangi dengan dilengkapi beberapa persyaratan yang sudah ada, termasuk sertifikat penyuluhan keamanan pangan. Jika semuanya sudah terpenuhi, maka dari pertugas pengawas yaitu petugas pengawas pangan Dinas Kesehatan Kabupaten Banyuwangi melakukan pemeriksaan sarana produksi pangan ke tempat Industri Rumah Tangga Pangan (IRTP) tersebut. Pemeriksaan sarana produksi pangan IRTP oleh
Dinas Kesehatan Kabupaten Banyuwangi rata-rata dalam sebulan \pm 10 buah yang harus dikunjungi untuk mendapatkan Nomor P-IRT.

Sedangkan berdasarkan Peraturan Kepala Badan Pengawas Obat dan Makanan Republik Indonesia Nomor Hk.03.1.23.04.12.2205 Tahun 2012 Tentang Pedoman Pemberian Sertifikat Produksi Pangan Industri Rumah Tangga bahwa pemeriksaan rutin IRTP akan dilaksanakan oleh petugas pengawas pangan puskesmas setempat yang diberi kewenangan oleh Dinas Kesehatan Banyuwangi. Pemeriksaan rutin dilaksanakan dua kali dalam setahun. (Gambar 2) Hal ini sejalan dengan penelitian sebelumnya (Pradita, 2013) yang menjelaskan bahwa pengawasan terkait sarana produksi pangan pada industri rumah tangga ini dilaksanakan oleh kepala dinas kesehatan yang diberikan kewenangansepenuhnya kepada kepala bidang masing-masing seksi.

Pada Bulan Maret-April 2018 pemeriksaan sarana produksi pangan dilakukan pada 15 Industri Rumah Tangga Pangan (IRTP). Dari hasil pemeriksaan tersebut (tabel. 4), Pertama, elemen lokasi dan lingkungan produksi memenuhi syarat. Semua IRTP memiliki lokasi dan lingkungan produksi yang terawat, bersih, dan tidak berdebu. Kedua, bangunan dan fasilitas ada 2 IRTP yang tidak memenuhi syarat, yaitu tidak ada kasa pada ventilasi dan pada bagian langit-langit tidak diberi plafon. Ketiga, Peralatan Produksi, ada 2 IRTP yang tidak memenuhi syarat yaitu peralatan yang bersih diletakkan pada tempat yang kotor dan tempat untuk membuat adonan berbahan dasar dari kayu yang lapuk. Keempat, sarana penyediaan air memenuhi syarat. 15 IRTP tersedia air bersih baik dari PDAM/BPSPAM maupun dari sumur.

Kelima, Fasilitas dan Kegiatan Higiene dan Sanitasi memenuhi persyaratan. Semua IRTP memiliki sarana pencucian alat dan bahan produksi dalam keadaaan terawat, tersedia sarana cuci tangan dengan menggunakan sabun dan alat pengering tangan, tersedianya toilet/jamban yang bersih, tersedia tempat sampah tertutup. Keenam, Kesehatan dan Higiene Karyawan ada 1 IRTP yang tidak memenuhi syarat yaitu karyawan bekerja dengan perilaku tidak baik seperti makan dalam pengemasan produk makanan. Untuk pakaian kerja kurang begitu diperhatikan dalam penilaian pemeriksaan. Sehinga karyawan tidak harus memiliki seragam kerja atau baju khusus untuk bekerja.

Ketujuh, Pemeliharaan dan Program Higiene dan Sanitasi ada 1 IRTP yang tidak memenuhi syarat yaitu dijumpai kucing berkeliaraan di sekitar tempat produksi pangan. Kedelapan, penyimpanan, ada 3 IRTP yang tidak 
memenuhi syarat yaitu meletakkan peralatan yang bersih pada tempat yang kotor, meletakkan bahan pangan pada lantai dan menempel dinding. Kesembilan, pengendalian proses memenuhi syarat. Semua IRTP menggunakan bahan baku dan bahan tambahan pangan yang benar. Kesepuluh, pelabelan pangan, ada 7 IRTP yang tidak memenuhi syarat antara lain: nama produk tidak disamakan; belum mencantumkan rancangan label pangan; tidak mencantumkan berat bersih, baik digunakan, kode produksi; nama produk tidak sesuai dengan produk makanan; tidak tersedia tempat untuk menuliskan PIRT. No... dan menuliskan -Tanpa Pengawetl; tidak tersedia tempat untuk menuliskan PIRT. No... dan penulisan label pangan terlalu kecil; kesalahan pada penulisan komposisiElemen penilaian kesebelas, pengawasan oleh penanggung jawab memenuhi syarat. Semua Pengelola IRTP dilakukan pengawasan IRTP selanjutnya atau pemeriksaan rutin oleh petugas pengawas pangan dari puskesmas setempat selama dua kali dalam setahun. Kedua belas, penarikan produk memenuhi syarat. Semua IRTP melaksanakan penarikan produk pangan yang masuk dalam kategori tidak aman. Ketiga belas, pencatatan dan dokumentasi memenuhi syarat. Semua IRTP memiliki dokumen produksi. Yang terakhir, pelatihan karyawan kurang sesuai dengan form penilaian yang seharusnya IRTP memiliki program pelatihan keamanan pangan untuk karyawan. Hanya saja dilihat dari pengelola IRTP yang memiliki sertifikat Penyuluhan Keamanan Pangan (PKP), sehingga semua IRTP memenuhi syarat.

Pemeriksaan sarana produksi pangan IRTP yang tidak memenuhi persyaratan harus melakukan saran perbaikan untuk mendapatkan SPP-IRT. Jangka waktu perbaikan sarana akan diputuskan oleh kedua belah pihak antara petugas pengawas pangan Dinas Kesehatan Banyuwangi dan pemilik atau penanggungjawab IRTP. Penanggungjawab atau pemilik IRTP bersama petugas pengawas pangan menandatangani formulir rincian laporan ketidaksesuaian. Pemilik IRTP melakukan konfirmasi kepada petugas pengawas pangan Dinas Kesehatan Banyuwangi setelah melakukan saran perbaikan. Kemudian petugas pengawas pangan menindaklanjuti dan memberikan keputusan kesesuaian sarana tersebut. Jika sudah sesuai, maka Dinas Kesehatan Banyuwangi berhak mengeluarkan SPP-IRT kepada pemilik atau penanggungjawab IRTP.
Dengan demikian, pada tahap ketiga ini, pemeriksaan sarana produksi pangan industri rumah tangga sudah sesuai dengan Peraturan Kepala Badan Pengawas Obat Dan Makanan Republik Indonesia Nomor Hk.03.1.23.04.12.2207 Tahun 2012 Tentang Tata Cara Pemeriksaan Sarana Produksi Pangan Industri Rumah Tangga.

\section{Pemberian Nomor P-IRT}

Sejak tahun 2012, nomor P-IRT berjumlah 15 digit dari sebelumnya hanya 12 digit. Dilihat dari jenis kemasan, dari 15 IRTP jenis kemasan yang banyak digunakan yaitu jenis kemasan plastik dengan diberikan kode (2) dan dua diantaranya menggunakan gelas (1) dan aluminium foil (5). Kode jenis pangan terdiri dari 8 IRTP menghasilkan tepung dan hasil olahannya (6), sebanyak 5 IRTP menghasilkan hasil olahan bijibijian dan umbi (15) sebanyak 5, serta 1 IRTP bumbu (11) dan 1 IRTP minuman ringan dan minuman serbuk (13). Kode Propinsi dan Kab/Kota Banyuwangi (3510). Digit 8-13 merupakan kode yang diberikan dari Dinas Kesehatan Banyuwangi berdasarkan nomor urut pangan IRTP yang telah memperoleh SPP-IRT dan nomor urut IRTP di Kabupaten Banyuwangi. Digit terakhir menunjukkan masa berlaku dari SPP-IRT pada tahun 2023 terhitung dari tahun pembuatan SPP-IRT pada tahun 2018. Pemberian Nomor PIRT pada 15 IRTP sudah sesuai dengan kertentuan 15 digit pada Perka BPOM RI. Meskipun dalam pemberian nomor tersebut terdapat IRTP yang harus melaksanakan saran perbaikan dari Petugas Pengawas Pangan Dinas Kesehatan Banyuwangi atau sarana produksi pangan IRTP tersebut sudah memenuhi standar yang ditentukan (tabel.5). Nomor P-IRT diberikan oleh Dinas Kesehatan Kabupaten Banyuwangi kepada Indstri Rumah Tangga Pangan (IRTP) yang memenuhi persyaratan sarana produksi pangan industri. Masa berlaku SPP-IRT ini selama 5 tahun. Hal ini sejalan dengan penelitian sebelumnya (Imtiyaz, 2016) bahwa masa berlaku SPP-IRT yang berlaku selama 5 tahun terhitung sejak IRTP memperoleh SPP-IRT. Jika sudah habis masa berlakunya, pemilik atau penanggungjawab wajib melakukan perpanjangan. IRTP akan dilakukan peninjauan sarana produksi pangan ulang oleh petugas pengawas pangan Dinas Kesehatan Banyuwangi.

\section{KESIMPULAN}

Pelaksanaan Sertifikasi Produksi Pangan Industri Rumah Tangga (SPP-IRT) yang diselenggarakan oleh Dinas Kesehatan Kabupaten Banyuwangi sudah sesuai dengan Peraturan Kepala Badan Pengawas Obat Dan 
Makanan Republik Indonesia Nomor Hk.03.1.23.04.12.2205 Tahun 2012 Tentang Pedoman Pemberian Sertifikat Produksi Pangan Industri Rumah Tangga.

\section{SARAN}

Seiring berjalannya waktu, keamanan dan mutu pangan menjadi prioritas utama bagi konsumen. Sehingga disarankan kepada pelaksana program untuk lebih memperhatikan setiap poin dalam elemen penilaian pemeriksaan IRTP. Untuk peniliti selanjutnya diharap menambahkan alasan sertifikasi tidak mencakup semua IRTP yang ada di Banyuwangi dan menciptakan aplikasi online untuk mempermudah registrasi permohonan SPP-IRT.

\section{DAFTAR PUSTAKA}

Dinas Kesehatan Kabupaten Banyuwangi. 2017. Profil Kesehatan Kabupaten Banyuwangi Tahun 2016. Diakses dari : http://www.depkes.go.id/resources/downl oad/profil/PROFIL_KAB_KOTA_2016/3 510_Jatim_Kab_BANYUWANGI_2016. pdf.

Dinkes Jatim. 2016. Profil Kesehatan Provinsi Jawa Timur Tahun 2016. Diakses dari: http://www.depkes.go.id/resources/downl oad/profil/PROFIL_KES_PROVINSI_20 16/15_Jatim_2016.pdf.

Ericko, M. Z. 2016. Evaluasi Kebijakan Sertifikasi Produksi Pangan Industri Rumah Tangga (Studi di Dinas Kesehatan Kota Bandar Lampung). (Skripsi, Universitas Lampung).Diakses darit: http://digilib.unila.ac.id/23943/.

Hermanu, B. 2014. Studi implementasi izin edar produk pangan industri rumah tangga (pirt) dalam mewujudkan keamanan pangan yang optimal di kota semarang, Hukum dan Dinamika masyarakat. doi: http://dx.doi.org/10.36356/hdm.v11i2.348

Imtiyaz, A. H. 2016. Analisis Nomor P-IRT pada Label Pangan Produksi IRTP di Kecamatan Kaliwates Kabupaten Jember. (Skripsi. Universitas Jember).Diakses dari:

http://repository.unej.ac.id/handle/123456 789/79561.

Kementrian Kesehatan RI. 2017. Profil Kesehatan Indonesia 2016. Diakses dari: http://www.pusdatin.kemkes.go.id/resour ces/download/pusdatin/profil-kesehatanindonesia/ Profil-Kesehatan-Indonesia2016.pdf.
Kepala BPOM. 2012. Peraturan Kepala Badan Pengawas Obat Dan Makanan Republik Indonesia Nomor Hk.03.1.23.04.12.2205 Tahun 2012 Tentang Pedoman Pemberian Sertifikat Produksi Pangan Industri Rumah Tangga. Diakses dari: http://standarpangan.pom.go.id/dokumen/ peraturan/2012/Perka_BPOM_No_HK.03. 1.23.04.12.2205_Tahun_2012_tentang_Se rtifikasi_Pangan_IRT.pdf.

Kepala BPOM. 2012. Peraturan Kepala Badan Pengawas Obat Dan Makanan Republik Indonesia Nomor HK.03.1.23.04.12.2207 Tahun 2012 Tentang Tata Cara Pemeriksaan Sarana Produksi Pangan Industri Rumah Tangga. Diakses dari: https://www.google.com/http:jdih.pom.go. id/showpdf.

Pradita.A, R. 2013. Implementasi Peraturan Kepala Badan Pengawas Obat Dan Makanan Republik Indonesia Nomor Hk.03.1.23.04.12.2205 Tahun 2012 Dalam Proses Pemberian Sertifikat Produksi Pangan Industri Rumah Tangga Di Dinas Kesehatan Kabupaten Kediri, Jurnal Ilmiah Universitas Brawijaya. Diakses dari:

http://download.portalgaruda.org/article.p hp? article $=187995 \&$ val $=6466 \&$ title $=$.

Purba, D. F., Nuraida, L. dan Koswara, S. 2014. Efektivitas Program Peningkatan Mutu Dan Keamanan Pangan Industri Rumah Tangga Pangan (Irtp) Di Kabupaten Cianjur', Jurnal Standardisasi, 16(2), pp. 103-112. doi: 10.31153/js.v16i2.172.

Sparringa, R. A. 2016. Laporan Tahunan Badan POM 2015. Diakses dari: http://www.pom.go.id/ppid/2016/kelengka pan/laptah2015.pdf.

UU RI. 2009. UU RI No 36 Tentang Kesehatan, UU RI No 362009.

WHO. 2005. Penyakit Bawaan Makanan Fokus Pendidikan Kesehatan. Diakses dari: http://apps.who.int/iris/bitstream/10665/42 428/3/9794487074_chapter1_ind.pdf. 